\title{
Çalışanların algılanan sosyal zekâlarının örgütsel iletişime etkisi
}

\author{
Necmiye Tülin IRGEa, Ayşegül ÖZKAN ${ }^{\mathrm{b}}$ Özlem Munise KAYNAK
}

\author{
a* Dr. Öğr. Üyesi, İstanbul Aydın Üniversitesi, i.i.B.F., İstanbul, Türkiye, E-posta: necmiyeirge@aydin.edu.tr ORCID ID https://orcid.org/0000-0001-9936-6229 \\ b* Doktora Öğrencisi, İstanbul Aydın Üniversitesi, I.I. B..F., İstanbul, Türkiye, E-posta: aysegulalibasoglu@stu.aydin.edu.tr ORCID ID https://orcid.org/ 0000-
} 0002-9625-0332

c* Doktora Öğrencisi, İstanbul Aydın Üniversitesi, I.I. B..F., İstanbul, Türkiye, E-posta: ozlemkaynak@stu.aydin.edu.tr ORCID ID https://orcid.org/ 0000-00019022-3467

\section{MAKALE BILGILERi}

Araştırma Makalesi

Geliş Tarihi 7 Ekim 2020

Revizyon 28 Kasım 2020

Kabul tarihi 29 Kasım

2020

\section{Özet}

Sanayi toplumundan bilgi toplumuna geçiş sürecinde örgütlerin varlıklarını sürdürebilmeleri için birçok farklı kaynağa ihtiyaç duyduğu bilinmektedir. Sürecin başlangııında çalışanların görevlerini belirtmek için sözlü veya yazılı bir süreç olarak benimsenen iletişim; daha sonra bilgi toplumunda vazgeçilmez bir kavram haline gelmiştir. Sürekli ve hızlı değişen günümüz koşulları, hem işletmeleri bu duruma uymaya ve sürekli yenilik yapmaya zorlamakta, hem de yoğun bir rekabetle karşı karşıya bırakmaktadır. Böylesi zorlu bir süreçte, işletmelerin değişime ayak uydurması ve rekabet üstünlüğü sağlaması için en önemli kaynaklarından birisi de insan kaynağıdır. Burada temel hedef yöneticilerin çalışanlardan daha etkin sonuç almaları, ikinci hedef ise çalışan memnuniyet düzeyinin yükseltilmesidir. Bu doğrultuda örgütsel iletişimin önemi göz ardı edilmemelidir. Örgütsel iletişim örgüt içinde ve örgütün çevresi ile arasındaki her türlü bilgi ve fikir alışverişi olarak tanımlanmaktadır. Sosyal zeka ise, bireyin diğer bireyler ile ilişkilerinde, ilişkiyi anlamlandırma, duygusal bağ kurma, işbirliği yapabilme yeteneği ve sosyal etkileşim becerisi olarak ifade edilmektedir. Bu çalışmanın amacı çalışanların algılanan soysal zekalarının örgütsel iletişimlerine etkisinin basit ve çoklu doğrusal regresyon analizi ile belirlenmesidir. Bu çalışmaya konu olan değişkenler, temelinde etkileşimin yer aldığı sosyal zekâ ve örgütsel iletişimdir. Araştırma 2019 yılı Kasım-Aralık aylarında kolayda örneklem yöntemi ile ulaşılan 385 çalışan üzerinde uygulanmıştır. Anketlerden elde edilen veriler SPSS istatistik programı çıktıları ile yorumlanmış ve hipotezler test edilmiştir. Araştırma yöntemi olarak basit ve çoklu regresyon analizi yapılmıştır. Araştırmanın sonucunda çalışanların algılanan sosyal zekâlarının örgütsel iletişime etkisinin çok düşük olduğu tespit edilmiştir. Gelecekteki çalışmalar için yorum ve önerilere de yer verilmekte ve çalışmanın hem literatüre hem de sektörel alana katkı sağlayacağı düşünülmektedir.

Anahtar Kelimeler: Sosyal Zeka, Örgütsel İletişim, Organizasyon, Örgütsel Davranış, İnsan Kaynakları

\section{The effect of employees 'social intelligence on organizational communications}

\section{ARTICLE INFO}

Research Article Received 7 October 2020 Received in revised form 28 November 2020 Accepted 29 November 2020

\section{Abstract}

It is known that organizations need many different resources in order to survive in the transition from industrial society to information society. Communication adopted as a verbal or written process to specify the duties of employees at the beginning of the process; later it became an indispensable concept in the information society. Continuous and rapidly changing today's conditions both force businesses to comply with this situation and constantly innovate, and confront an intense competition. In such a challenging process, one of the most important resources for businesses to adapt to change and gain competitive advantage is human resources. Here, the main goal is for managers to get more effective results from employees, and the second goal is to increase employee satisfaction In this direction, the importance of organizational communication should not be overlooked. Organizational communication is defined as the exchange of information and ideas within the organization and with its environment. Social intelligence, on the other hand, is expressed as the ability to make sense of the relationship, establish an emotional connection, cooperate and social interaction skills in the individual's relationships with other individuals. The aim of this study is to determine the effect of perceived social intelligence of employees on organizational communication using simple and multiple linear regression analysis. The variables subject to this study are social intelligence and organizational communication, which is based on interaction. The research was conducted on 385 employees, who were accessed by convenience sampling method, in November-December 2019. The data obtained from the surveys were interpreted with the outputs of the SPSS statistics program and the hypotheses were tested. Simple and multiple regression analysis was used as a research method. As a result of the research, it was determined that the effect of perceived social intelligence of employees on organizational communication was very low. Comments and suggestions are also included for future studies and it is thought that the study will contribute to both the literature and the sectoral field.

Key Words: Social Intelligence, Organizational Communication, Organization, Organizational Behavior, Human Resources

\section{Giriş}

Yönetim teorileri incelendiğinde geçmişten günümüze kadar insan kaynağına verilen değerin gittikçe arttığı görülmektedir. Literatürde işletme yönetimi ile ilgili değişkenler farklı disiplinlerdeki değişkenler ile bir araya getirilerek; örgütsel davranış biçimlerinin anlaşılması sağlanmaya çalışılmıştır. Örgütsel davranış çatısı altındaki motivasyon, iş tatmini, kişilik, öğrenme, örgüt kültürü ve örgütsel iletişim gibi kavramlar; psikoloji, sosyoloji ve sosyal psikoloji alanlarındaki incelemeler ile bütünleştirilerek çeşitli yorumlara ulaşılmıştır.

Yönetim alanında önemli bir yere sahip olan örgütsel davranış, örgüt içindeki çalışanların faaliyetlerini gerçekleştirirken sergiledikleri davranışları ifade etmektedir. Ayrıca bireylerin davranışlarını nedensellik ile inceleyen örgütsel davranış, sorunların çözüme kavuşturulması ve örgütün verimliliğinin arttırılmasına yönelik süreçleri belirlemeye yöneliktir. Örgütsel davranış çatısı altında çalışanlar ve örgüt uyumunu inceleyen tüm araştırmaların öncelikli hedeflerinin; çalışanların memnuniyetini arttırmak, örgütlerin etkinlik ve verimliliğini arttırmak, dolaylı olarak da örgütün hedeflerine ulaşmasını ve piyasada sürdürülebilir rekabet avantajı elde etmek olduğu gözlemlenmektedir.

Insan olmanın temelinde davranışları etkileyen duygular ve düşünceler yatmaktadır. Duygu ve düşüncelerin aktarımında kullanılan iletişim ise hem bireyler hem de işletmeler için büyük bir önem arz etmektedir. Duyguları çözümleyebilme, insan ilişkilerini anlamlandırma çalışanlar açısından önemli bir meziyet olmakla birlikte, işletmelerin de örgütsel iletişimin gelişmesi ile ilgili ne gibi uygulama ve politikaları olduğu da hem işletmenin başarısı ve sürdürülebilirliği 
açısından hem de çalışanların kendi başarı ve mutlulukları açısından önemlidir. Tam da bu noktada bireyin diğer bireyler ile ilişkilerinde; ilişkiyi anlamlandırma, duygusal bağ kurma, işbirliği yapabilme yeteneği ve sosyal etkileşim becerisi olarak tanımlanan sosyal zekanın örgüt içi iletişimde olduğu kadar tüm paydaşlar ile etkin bir iletişim kurmada etkili olacağı düşünülmektedir.

Çalışanların algılanan sosyal zekalarının örgütsel iletişime etkisinin olup olmadığını belirlemek amacıyla literatürde detaylı bir inceleme gerçekleştirilmiştir. Örgütsel davranış ile ilgili araştırmalarda daha çok duygusal zekanın ilişkisel, yordayıcı veya aracı olduğu saptanmıştır. Özellikle sosyal zeka ve örgütsel iletişim, kültür açııından literatürümüzdeki bulgularla karşılaştııılacaktır. Yabancı dizindeki araştırmalar ile birlikte de değerlendirmeye alınacak olan bu kavramlar, teorik çerçeveye konumlandırılarak bulgular ile desteklenecektir.

\section{Literatür Taraması}

Bu araştırmada ele alınan değişkenler örgütsel iletişim ve sosyal zekadır. Yapılan literatür taramasında işletme bilim dalı altında bu iki değişkenin farkı değişkenler ile birlikte incelendiği görülmekle beraber, sosyal zeka ve örgütsel iletişimin tek bir çalışma altında incelendiği bir araştırmaya rastlanmamıştır. Bu konuda bir araştırma boşluğu olduğu saptanarak değişkenler ayrı ayrı çalışmalardan elde edilen bilgiler ışığı altında incelenmiştir.

Yerel literatürde bu iki değişken farklı araştırmacılar tarafından ele alınmıştır. Şenkal (2019)'a ait çalışmada sosyal zeka seviyesi ile çatışma yönetimi tarzları arasında düşük seviyede pozitif bir ilişki; Yıldırım (2018)'a ait çalışmada sosyal zeka ile problem çözme yeteneği arasında orta seviyede pozitif bir ilişki; Berk (2016) tarafından gerçekleştirilen araştırmada ise sosyal zekanın ve tükenmişliğin boyutları arasındaki ilişki incelenmiş ve boyutlar arasında değişik seviyelerde ilişkiler tespit edilmiştir. Diktaş (2018) yaptığı çalışmada örgütsel sinizm ve sosyal zekânın işten ayrılma niyeti üzerinde anlamlı bir etkisinin olduğu sonucuna ulaşmıştır. Tekin'e (2019) ait araştırmada sosyal zekânın akademik performans üzerindeki etkisinde kültürel zekânın düzenleyici bir rol üstlendiği sonucuna varılmıştır. Diğer bir araştırmada sosyal zeka; yaşam doyumu ile iş doyumu arasındaki ilişkide aracı rol olarak incelenmiş ve analizler sonucu, yaşam doyumunun iş doyumu üzerindeki etkisinde sosyal zekanın aracılığının bulunduğu belirlenmiştir (Bayram \& Elevli, 2019). Yabancı literatür incelendiğinde YahyazadehJeloudar \& Lotfi-Goodarzi (2012) sosyal zeka ve iş tatmini ile ilgili araştırmalarında anlamlı bir ilişki; Dong, Koper \& Collaç̧o (2008) ise gerçekleştirdikleri araştırmada sosyal zeka ve kültürler arası iletişim hassasiyeti arasında anlamlı bir ilişki olduğunu ortaya koymuştur.

Örgütsel iletişim ise işletme bilim dalı altındaki araştırmalarda çok sık rastlanan bir kavramdır. Yılmaz (2019)'a ait araştırmada örgütsel iletişimin dönüşümcü liderlik davranışları ile ilişkisi incelenmiştir ve araştırmanın sonucunda pozitif yönde anlamlı bir ilişki tespit edilmiştir. Çiftçi (2019) örgütsel iletişim tarzının örgütsel bağııı̆̆a etkisini incelediği araştırmada, örgütsel iletişimin örgütsel bağılık ve örgütsel bağ|ılığın alt boyutları üzerinde pozitif anlamlı bir etki tespit etmiştir. Aydoğdu (2016) çalışmasında örgütsel iletişim algısının örgütsel vatandaşıı davranışına etkisini incelemiş ve araştırmanın sonucunda pozitif anlamlı bir etki saptamıştır. Kılıç ve Saygılı (2019) örgütsel iletişimin örgütsel sessizliğe etkisini incelemiş, araştırmanm sonucunda örgütsel iletişim ve örgütsel sessizlik arasında negatif yönlü anlamlı bir ilişki olduğunu tespit etmiştir. Koçer, Yeşil \& Yürüyen (2019) kaleme aldıkları çalışmada sanallık algısının, iş yeri yalnızlığı ve örgütsel iletişim üzerindeki etkisini incelemiş ve araştırmanın sonucunda, sanallık algısının, iş yeri yalnızlığı ve örgütsel iletişim üzerinde pozitif etkisi olduğu bulgusuna ulaşmışırı. Yabancı literatürde ise Young-Soo, Marcia \& Eun-sil (2019) araştırmalarında örgütsel iletişim ve iş tatmini arasında anlamlı bir ilişki; Hanisha \& Hidayat (2019) örgütsel iletiş̧im ikliminin çalışan performansına etkisini ele aldıkları araştırmalarında anlamlı bir etki tespit etmişlerdir.

Yukarıda bahsedilen çalışmalarda sosyal zeka ve örgütsel iletişim değişkenlerinin farklı değişkenler ile ele alındığı ve genel olarak ilgili değişkenler üzerinde pozitif etkilerinin olduğu görülmektedir. Sosyal zeka ve örgütsel iletişim değişkenlerinin birlikte ele alınması durumunda; aralarında pozitif bir ilişki ve etki saptanacağı tahmininden yola çıkılarak bu araştırma yapıımıştır.

\section{Kavramsal Çerçeve}

\section{Sosyal Zeka}

Sosyal zeka kavramı literatürde öncelikli olarak Dewey (1909) ve Lull (1911) tarafından kullanılsa da (Kihlstrom \& Cantor, 2000:564), asıl detaylı inceleme Thorndike (1920) tarafından yapılmıştır. Thorndike (1920:228) tarafından incelenen "diğer bireylerle ilişkilerde yetenekli olma ve diğer insanları anlama yeteneği" olarak tanımlanan psikoloji bilim dalının önemli kavramlarındandır. Goleman (2019:8) sosyal zeka kavramını "Insan ilişkilerinin yeni bilimi" olarak tanımlamış ve "bu yeni bilimin en temel keşfinin beynimizin birbirimiz ile bağlantı kurmamızı sağlayacak şekilde donaltılmış olduğu" şeklinde aktarmıştır. Silvera Martinussen \& Dahl (2001:316) çalışmasında sosyal zekayı, "sosyal bilgi süreci, sosyal beceri ve sosyal farkındalık" olmak üzere üç boyutta incelemiştir. Çavuş, Pekkan \& Develi (2019:261) Sosyal bilgi süreci ile ilgili "bireyin diğer bireylerle olan ilişkisinde duygu ve düşünceleri anlayabilmesi, beden dili ile aktarılan tepkileri yorumlayabilmesi ve karşı tarafın beklentilerini tahmin edebilmesi gibi çeşitli becerilerinden oluşmaktadır", sosyal beceri ile ilgili "davranışa dönüştürülmüş sosyallik", sosyal farkındalık için ise "bireyin bulunduğu koşullara kolay uyum sağlayabilme yeteneği" tanımını kullanmıştır.

Çoklu zeka kuramından hareketle ön plana çıkan ve özellikle psikoloji literatüründe sıkça araştırılan kavram olan sosyal zeka, bireylerin güçlü bir etkileşim ve iletişime geçme becerisi olarak ifade edilmektedir (Şenkal, 2019: 18). Sosyal zeka yaşadığımız çevrede olup bitenleri kişisel ve sosyal açıdan anlamak açısından büyük önem taşımaktadır (Lacanlale, 2013:263).

Sosyal zekası ileri olan bireyler liderlik özellikleri ile ön plana çıkmaktadır; bunun yanında iletişim kabiliyetleri güçlü olan bu bireyler vücut dilini kullanmada ve arkadaşlık kurma konusunda becerikli, işbirliği içerisinde çalışmaya yatkındırlar (Topses, 2009: 65; Cemaloğlu ve Yıldırım, 2005:40).

\section{Örgütsel iletişim}

Illetişim sözcüğü TDK tarafından "duygu, düşünce veya bilgilerin akla gelebilecek her türlü yolla başkalarına aktarılması, bildirişim, haberleşme, komünikasyon" şeklinde tanımlanmaktadır (https://sozluk.gov.tr/). Iletişim statik bir yapıda değildir, gelişime açık bir yapıda olduğu için süreç olarak tanımlanmaktadır (Roberts \& O'Reilly, 1974:321). Örgüt ise "birden fazla kişinin belirli bir amaç etrafında bilinçli olarak oluşturduğu güç ve eylem birliğidir" (Güney, 2017:3). Söz konusu bu örgütlerin oluşabilmesi ve hayatlarına devam edebilmesi amacıyla en temel ihtiyaçları iletişimdir. Iletişim olmaksızın örgütleme ve düzenleştirme sağlanamaz (Atak, 2005: 60).

Örgütsel iletişim kavramı bir örgütün amaç ve hedeflerini gerçekleştirme doğrultusunda bilgi akışını sağlayabilmek adına çalışanların sürekli etkileşim ve işbirliği hâlinde olmaları şeklinde tanımlanabilmektedir (Tutar, 2003: 83). Örgütsel iletişim bir örgütün çalışanlarının sadece kendi aralarında bilgi alışverişinde bulunması olarak değerlendirilmemelidir, örgütün ilişkide olduğu tüm kurumsal paydaşları ile iletişimini de ele almaktadır (Çelikdemir \& Paker, 2019:432). Sürdürülebilir rekabet avantajı sağlayabilmek ve müşteri memnuniyeti sağlamak açısından örgütlerin iletişim seviyelerini yüksek tutmaları gerekmektedir (Akkaya ve Tabak, 2018:186).

Örgütsel iletişimin amacı oluşturulan hedefe yönelik bilgi vermek, yönlendirmek ve sosyal ilişkileri düzenlemektir. Örgütsel iletişim çalışanların "algısal, bilişsel, coşkusal, duygusal, duyuşsal ve entellektüel” olarak iletişimde bulunabilmesi açısından önemlidir (Marşap, 2017:363). Mcshane \& Von Glinow (2016:154) iletişim sürecinin etkinliğini "kaynağın ve alııının enformasyonu etkin ve doğru bir şekilde kodlama ve çözümle yeteneği ile yakından ilişkili" olduğunu belirtmiştir. Örgütlerde köprü vazifesi gören iletişimin en etkili özelliğinin haber ve bilgi yayılmasını sağlaması, eksikliğinde ise örgütün yaşamını kısaltıcı ve sonlandırıcı olduğu belirtilmiştir (Kocabaş, 2005:249).

\section{Araştırmanın Metodolojisi}

\section{Veri Toplama ve Veri Toplama Aracı}

Literatürde sosyal zeka ile ilgili bir çok çalışma mevcuttur. Fakat örgüt iletişimi ile ilişkisini inceleyen herhangi bir çalışmaya rastlanmamıştır. Bundan dolayı bu araştırmanın önemli olduğu ve literatüre katkıda bulunacağı düşünülmektedir. Örgüt yaşantısında sosyal zekanın önemine dikkat çekmek amacıyla gerçekleştirilen bu çalışma, akademi ve iş dünyasına yeni bir bakış açısı kazandırma eğiliminden dolayı oldukça önemli olduğu düşünülmektedir. 2019 yılı Kasım- 
Şekil 1: Örneklem formülü

$$
\mathrm{n}=\frac{\mathrm{N} \mathrm{t}{ }^{2} \mathrm{pq}}{\mathrm{d}^{2}(\mathrm{~N}-1)+\mathrm{t}^{2} \mathrm{pq}}
$$

$\mathrm{n}=$ Ömeklem büyüklüğü

$\mathrm{N}=$ Anakütle (evren) (4 milyon 137 bin 618)

$\mathrm{p}=$ Olaym gerçekleşme olas 1 l.ğ $1(0,5)$

$\mathrm{q}=$ Olaym gerçekleşmeme olasilı̆̆ $(0,5)$

$\mathrm{t}=\mathrm{t}$ test düzeyi $(1,96)$

$\mathrm{d}=$ Hata pay $1 \% 5)$

\%5 hata payı ile anakütleyi temsil edecek örneklem büyüklüğünün en az 384 çalışan olması gerektiği saptanmıştır. Neden-sonuç ilişkisinin araştırılarak, sosyal zeka değişkenin örgütsel iletişim değişkenine etkisinin sorgulandığı bu çalışma için kolayda örnekleme yöntemi uygulanmıştır. ỉhtiyaç duyulan örnekleme ulaşıncaya kadar en kolay ve ulaşılabilir deneklerden veri toplayarak oluşturulan örnekleme yöntemi olarak bilinen bu metot (Gürbüz \& Şahin, 2018: 132) ile araştırma için İstanbul ilindeki 411 çalışana yüzyüze ve online ortamda ulaşılmışır. Anketlerdeki eksik bilgiler ve hatalı işaretlemelerden dolayı 26 kişinin anketleri elenerek, 385 kişinin yanıtları ile analiz yapılmışır. Araştırmanın 2019 Kasım- Aralık ayları içerisinde gerçekleştirilmesi sebebi ile etik izne başvurulmamıştır.

Araştırmada nicel bir yöntem olan anket yöntemi uygulanmıştır. Değişkenlere ilişkin ifadelere geçmeden önce demografik bilgileri sağlama amaçlı 8 maddelik formdan yararlanılmıştır. Sosyal zeka değişkenine ilişkin Silvera, Martinussen \& Dahl (2001) tarafından geliştirilen, geçerlilik ve güvenirliği Doğan \& Çetin (2009) tarafından yapılarak literatürümüze kazandırılan "Tromso Sosyal Zeka Ölçeği” kullanılmıştır. Ölçek 21 ifadeden oluşmaktadır. Örgütsel iletişim değişkenine ilişkin ölçek ise, Gürgen (1997) tarafından geliştirilen 9 ifadelik bir ölçektir. Iki ölçekteki ifadeler 5'li Likert Ölçeği (1=Hiç Katılmıyorum, 2=Katılmıyorum, 3=Kararsızım, 4= Katıııyorum, 5=Kesinlikle Katıılıorum) ile yanıtlayıcılara yönlendirilmiştir. Araştırmanın modeli Şekil 2'de gösterildiği gibidir.

Şekil 2: Araştırmanın modeli

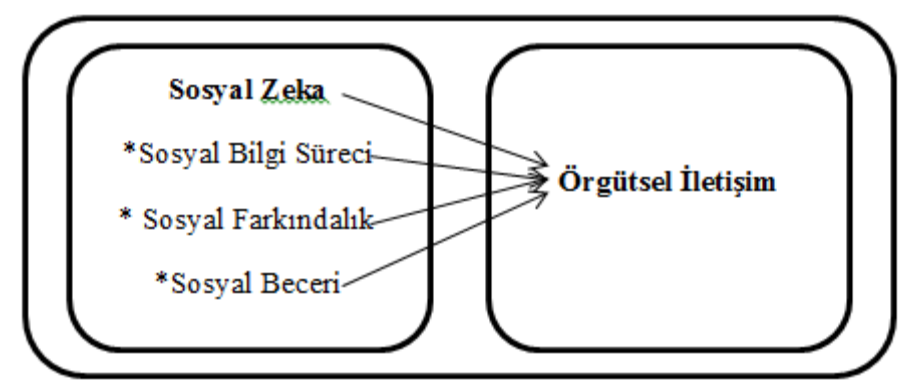

Modele ilişkin hipotezler:

$\mathrm{H}_{1}$ : Çalışanların algılanan sosyal zekalarının örgütsel iletişim üzerinde etkisi vardır.

$\mathrm{H}_{1 \mathrm{~A}}$ : Sosyal bilgi sürecinin örgütsel iletişime etkisi vardır.

$\mathrm{H}_{18}$ : Sosyal farkındalığın örgütsel iletişime etkisi vardır.

$\mathrm{H}_{1 \mathrm{c}}$ : Sosyal becerinin örgütsel iletişime etkisi vardır.

\section{Bulgular}

\section{Frekans Analizlerine ilişkin Bulgular}

Araştırmanın gerçekleştirildiği örneklem grubundaki dağılımlar incelendiğinde, çoğunlukta ankete katılanların \%53,8'i kadın, \%36,4'ü 25-32 yaş aralığında, $\% 55,3^{\prime}$ ü bekar, \%55,1'i üniversite mezunu, \%66'sı 4501 TL ve üzeri gelir sahibi, \%91,7'si beyaz yaka, \%33,8'i şuandaki iş yerinde 1 yıldan az süre ile çalışmakta, $\% 45,5^{\prime}$ i ise 9 yıl ve üzeri toplam iş tecrübesine sahiptir. Frekans tablosuna ilişkin bilgiler Tablo 1'de yer almaktadır.

Tablo 1: Katılımcılara ait demografik özellikler

\begin{tabular}{|c|c|c|c|}
\hline & & Frekans (n) & Yüzde (\%) \\
\hline \multirow{3}{*}{ Cinsiyet } & Kadın & 207 & 53,8 \\
\hline & Erkek & 178 & 46,2 \\
\hline & Toplam & 385 & 100,0 \\
\hline \multirow{4}{*}{ Yaş } & $18-24$ yaş & 61 & 15,8 \\
\hline & $25-32$ yaş & 140 & 36,4 \\
\hline & $33-40$ yaş & 82 & 21,3 \\
\hline & 41 yaş ve üzeri & 102 & 26,5 \\
\hline \multirow{3}{*}{ Medeni Durum } & Evli & 172 & 44,7 \\
\hline & Bekar & 213 & 55,3 \\
\hline & Toplam & 385 & 100,0 \\
\hline \multirow{4}{*}{ Eğitim Düzeyi } & Ortaöğretim ve Lise & 51 & 13,2 \\
\hline & Yüksekokul & 36 & 9,4 \\
\hline & Üniversite & 212 & 55,1 \\
\hline & Lisansüstü (Yüksek Lisans ve Doktora) & 86 & 22,3 \\
\hline Gelir Düzeyi & 3500 TL ve altı & 88 & 22,9 \\
\hline
\end{tabular}




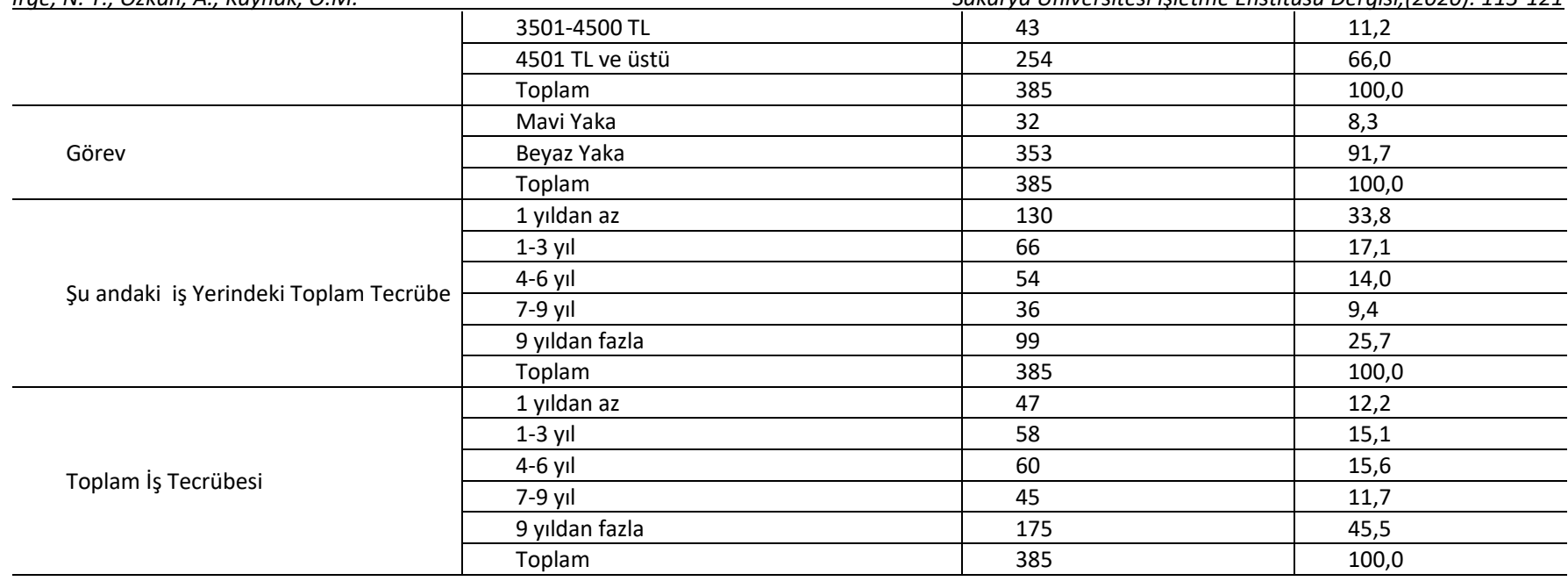

\section{Açıklayıcı faktör analizi ve güvenirlik analizine ilişkin bulgular}

Tromso Sosyal Zeka Ölçeği (TSZÖ) Silvera ve arkadaşları (2001) tarafından, sosyal zeka düzeyini ölçmek üzere yirmi bir madde olarak hazırlanmış bir ölçme aracıdır. Doğan \& Çetin (2009) ölçeğin Türkçe uyarlamasını yapmışlardır. TSZÖ, sosyal zekayı üç alt boyutta ölçmektedir. Sosyal Bilgi Süreci faktörü 1, 3, 6, 9, $14,15,17,19$ ifadelerinden oluşmaktadır, alt boyuttan alınabilecek en yüksek puan 40'dır. Iletişimdeki sözlü ya da sözsüz mesajları anlama, empati, iletişim de açık olmayan mesajları anlayabilme becerilerini ölçmektedir. Sosyal Beceri faktörü 4, 7, 10, 12, 18, 20 ifadelerinden oluşmaktadır, alt boyuttan alınabilecek en yüksek puan 30'dur. Dinleme, atılganlık, ilişki kurma, devam ettirme ve bitirme gibi temel iletişim becerileri ölçülmektedir ve Sosyal Farkındalık faktörü de 2 , $5,8,11,13,16,21$ ifadelerinden oluşmaktadır, alt boyuttan alınabilecek en yüksek puan 35'dir. Bireyin çevresine, bulunduğu mekana ve zamana göre uygun olan davranış becerileri ölçülmektedir. Ölçeğin Cronbach alfa iç tutarlılık kat sayıları testin geneli için 0,830 , sosyal bilgi süreci faktörü için 0,810 , sosyal beceri faktörü için 0,860 ve sosyal farkındalık faktörü için 0,790 'dır. Geçerlilikse ölçeğin orijinal halinde uzman görüşü alınmış, yapı geçerliğine bakılmış ve benzer ölçeklerin geçerliği incelenmiştir. Madde havuzunda yüz üç madde içerisinde faktör yükü 0,450'den büyük ve korelasyonu 0,300 olan yirmi bir madde seçilmiştir. Bu seçilen maddelere varimax döndürme yöntemi ile kuramsal temelle örtüşen üç faktör belirlenmiştir. Benzer ölçek geçerliği ise Marlowe Crowne Social Desirability Scale (MSCD) ile incelenmiş ve 0,220 korelasyon bulunmuştur. İncelenen çalışmalara göre ölçeğin geçerli ve güvenilir olduğu görülmüştür.

$\mathrm{Bu}$ araştırmada ise sosyal zeka ölçeği için KMO testi yapılmış, KMO değeri \%0,869 olarak tespit edilmiştir. \%0,869>0,50 olduğu için veri setinin, faktör analizi için uygun olduğu söylenebilmektedir. Yapılan Bartlett testinin sonucunda $p=0,000<0,01$ değeri analiz yapılmaya uygun bulunmuştur (Durmuş vd., 2018: 80). Bu sonuç boyutlar arasındaki yüksek korelasyonun varlığını ortaya koymaktadır. Yani veri seti faktör analizi için uygundur. Güvenirlik analizi sonucunda elde edilen genel Cronbach Alfa katsayıları; sosyal bilgi süreci boyutu için 0,787, sosyal beceri boyutu için 0,809 ve sosyal farkındalık boyutu için 0,704 olarak tespit edilmiştir. Bu sonuç ölçeğin yüksek güvenirlikte olduğunu göstermektedir (Özdamar'dan akt. Kılıç, 2016:48). Yapılan faktör analizi sonucunda sosyal zeka değişkenin 3 boyutu olduğu tespit edilmiştir. Faktör yükleri düşük olarak tespit edilen 2., 12., 13., 15., 16., 19., 21. ifadeler teker teker çıkartılarak yapılan faktör analizine ilişkin bulgular Tablo 2'de yer almaktadır.

Tablo 2: Sosyal zeka değişkenine ait faktör analizi

\begin{tabular}{|c|c|c|c|c|}
\hline & & Faktör Yükleri & Varyans Yüzdesi & Cronbach Alfa \\
\hline \multirow{6}{*}{ Sosyal Bilgi Süreci } & S6 & 0,748 & \multirow{6}{*}{22,261} & \multirow{6}{*}{0,787} \\
\hline & S14 & 0,699 & & \\
\hline & S3 & 0,650 & & \\
\hline & S17 & 0,637 & & \\
\hline & S9 & 0,634 & & \\
\hline & S1 & 0,586 & & \\
\hline \multirow{5}{*}{ Sosyal Beceri } & S10 & 0,796 & \multirow{5}{*}{19,566} & \multirow{5}{*}{0,809} \\
\hline & S7 & 0,763 & & \\
\hline & S18 & 0,712 & & \\
\hline & S4 & 0,595 & & \\
\hline & S20 & 0,583 & & \\
\hline \multirow{3}{*}{ Sosyal Farkındalık } & S8 & 0,791 & \multirow{3}{*}{15,605} & \multirow{3}{*}{0,704} \\
\hline & S11 & 0,748 & & \\
\hline & S5 & 0,647 & & \\
\hline
\end{tabular}

Örgütsel iletişim ölçeği için ise yapılan KMO testinde KMO değeri 0,920 olarak tespit edilmiştir. \%0,920>0,50 olduğu için veri setinin, faktör analizi için uygun olduğu söylenebilmektedir. Yapılan Bartlett testinin sonucunda analiz yapılmaya uygun olduğu ( $p=0,000<0,01$ ), güvenirlik analizinde ise Cronbach Alfa katsayısının 0,938 olduğu, örgütsel iletişim değişkeninin faktör analizi sonucunda tek boyutlu olduğu tespit edilmiştir. Cronbach Alfa katsayısı düşük olarak tespit edilen 1. ifade analiz sırasında devre dışı bırakılmıştır. Örgütsel iletişim değişkenine ilişkin faktör analizi bulguları Tablo 3’te gösterildiği gibidir.

Tablo 3: Örgütsel iletişim değişkenine ait faktör analizi

\begin{tabular}{r|r|r|r|r}
\multicolumn{6}{c}{ Tablo 3: Orgütsel iletişim değişkenine ait faktör analizi } \\
\hline & Madde & Faktör Yükleri & Varyans Yüzdesi & Cronbach Alfa \\
\hline & S7 & 0,885 & \multirow{2}{*}{69,935} & 0,938 \\
\cline { 2 - 3 } & S5 & 0,873 & & \\
\hline
\end{tabular}




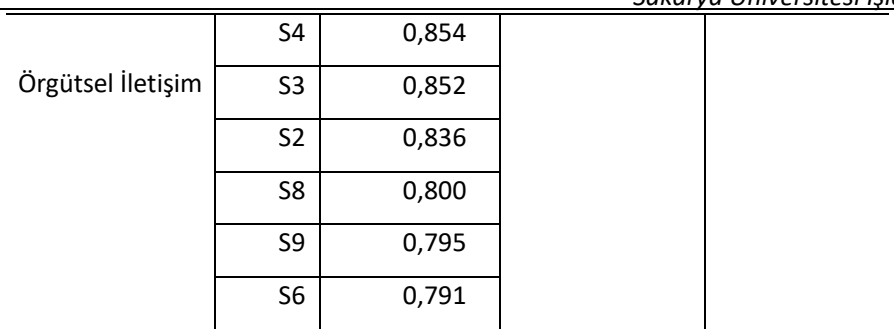

\section{Doğrulayıcı Faktör Analizine iliş̧in Bulgular}

Doğrulayıı faktör analizinin sonuçlarını değerlendirmek için Anderson ve Gerbing'in (1992) iki aşamalı yaklaşımı temel alınmışır. Bu yaklaşım, yapısal modeli test etmeden önce Açıklayıcı Faktör Analizi (AFA) ve Doğrulayıcı Faktör Analizi (DFA) yapılması gerektiği ifade edilmiştir. AFA, gözlenen değiş̧kenler arasındaki ilişkiye dayanır. Fakat DFA kovaryans tabanını esas alır. Başka bir ifade ile kullanılan yapılara ait ölçeklerin AFA ile geçerliliği test edilirken DFA ise kalitesi test edilir (Hair vd., 2010). Bu araştırma da önce AFA yapılmış ölçeklerin geçerliliği test edilmiştir. Daha sonra ortaya çıkan yapı DFA ile test edilmiştir. Tüm yapılar, AMOS (Analysis of Moment Structures) 22.0 istatistik yazııımı kullanılarak test edilmiştir. Testlere başlamadan önce gerekli bazı koşullar kontrol edilmiştir.

DFA'nın kalitesinin değerlendirilmesinde kullanılan bazı göstergeler mevcuttur. Özellikle yaygın uyum indeksleri model uygunluğunu değerlendirmede kullanılır. Çoğu çalışmada, $X^{2}$ değeri bir başlangıç noktası olarak kabul edilir (Hair vd., 2010; Hatcher, 1994). Bu bağlamda $X^{2}$ değerinin azalması verinin daha iyi bir uyum gösterebileceğini ifade eder (Hatcher, 1994). Fakat Kline (2005) ise $X^{2}$ değerinin büyük örneklemli araştırmalar için tek başına yeterli uyum göstergesi olmadığını ifade etmiştir. Bu araştırmada da örneklem büyüklüğü 385 olması nedeni ile diğer uyum indeksleri de modelin uygunluğunun değerlendirilmesinde kullanılmıştır. Önerilen uyum indeksleri aşağıdaki tabloda gösterilmiştir.

Tablo 4: Önerilen uyum indeksleri

\begin{tabular}{|c|c|c|}
\hline Uyum Indeksi & Iyi Uyum & Kabul \\
\hline$x^{2}$ & $0 \leq x 2 \leq 2 s d$ & $2 s d \leq x 2 \leq 3 s d$ \\
\hline p değeri & $.05 \leq p \leq 1.00$ & $.01 \leq p \leq .05$ \\
\hline \multirow{4}{*}{ Normlaştırılmış X2 } & $0 \leq x^{2} / \mathrm{sd} \leq 2$ & $2 \leq x 2 / s d \leq 3$ \\
\hline & $\begin{array}{l}\leq 2.5 \text { mükemmel uyum } \\
\text { (küçük örneklemlerde) }\end{array}$ & (Kline, 2005) \\
\hline & $\begin{array}{c}\leq 3 \text { mükemmel uyum (büyük } \\
\text { örneklemlerde) }\end{array}$ & $\begin{array}{l}\text { (Kline, 2005; } \\
\text { Sümer, 2000) }\end{array}$ \\
\hline & (Sümer, 2000) & $\leq 5$ orta \\
\hline RMSEA & $0 \leq \mathrm{RMSEA} \leq .05$ & $.05<$ RMSEA \\
\hline RMR/SRMR & $0 \leq \mathrm{RMR} \leq .05$ & $.05<\mathrm{RMR} \leq$ \\
\hline $\mathrm{NFI}, \mathrm{CFI}, \mathrm{GFI}, \mathrm{TLI}$ & $.95 \leq \mathrm{NFI} \leq 1.00$ & $.90 \leq \mathrm{NFI} \leq .95$ \\
\hline
\end{tabular}

Kaynak: (Kline, 2005).

(Not: RMSEA= Root Mean Square Error of Approximation, RMR= Root Mean Square Residual, $\mathrm{NFI}=$ Normed Fit Index, $\mathrm{CFI}=$ Comparative Fit Index, GFI= Goodness of Fit Index,

$\mathrm{TLI}=$ Tucker-Lewis Index.)

Birçok Yapısal Eşitlik Modeli (YEM) çalışmalarında kullanılan yaygın uyum indeksleri, modelin uygunluğunu değerlendirmede kullanılır. Bu indekslerden mutlak (absolute) uyum indeksleri $\mathrm{X}^{2}$, GFI, RMSEA, RMR, SRMR ve Standartlaştıılmış $\mathrm{X}^{2}$ indeksleridir. NFI, TLI, CFI ve RFI artan (incremental) uyum indeksleridir. AGFI ve PNFI sıkılık (parsimony) uyum indeksleridir (Hair vd., 2010; Şeşen \& Meydan, 2011). Hair vd. (2010), yapmış olduğu çalışmada bir mutlak uyum indeksi ve bir artan uyum indeksinin $X^{2}$ değeri ile birlikte raporlanmasını önermiştir. Bu çalışmada mutlak uyum indeksleri olarak $\mathrm{X}^{2}$, Standartlaştıılmış $\mathrm{X}^{2}$, GFI, RMSEA, RMR ve artan uyum indeksleri olarak da NFI, TLI ve CFI kullanılarak test edilecektir. Tablo 4 'de literatürde yer alan bu genel uyum indekslerinin kabul edilebilir kesme noktaları belirtilmiştir (Ho, 2014; Şeşen \& Meydan, 2011; Arıkan, 2010; Şimşek, 2007; Schumacker \& Lomax, 2004; Schermelleh-Engel vd., 2003; Bryne, 2001; Tabachnick \& Fidell, 2001; Hu \& Bentler, 1999). Ölçüm modelinin DFA sonuçları $\chi^{2}(63)=100,729(p \leq 0,05)$ olduğunu göstermektedir. Yukarıda bahsedildiği gibi $X^{2}$ değerinin beklenen anlamlı düzeyindedir. Hair vd. (2010) ki-kare değeri örneklemin büyüklüğüne duyarlı olmasından dolayı $X^{2}$ ile birlikte diğer uyum indekslerinin de dikkate alınmasını önermiştir. Aksi takdirde "Sadece $X^{2}$ değerine güvenmek, gerçekte doğru olan (kabul edilmesi gereken) sıfır hipotezinin reddetme olasılığııı ifade eden tip 1 hatasına neden olabilmektedir." şeklinde ifade edilmiştir. Bu kapsamda en iyi indeks uyum değerlerini veren modeller dâhilinde araştırma modellerinin test edilmesi gerekmektedir (Usluel, Demir \& Çınar, 2014; Çokluk, Şekercioğlu \& Büyüköztürk, 2012; Şeşen \& Meydan, 2011; Noar, 2003). Tablo 4'de önerilen uyum indekslerine göre, bir bütün olarak ölçüm modelinin uyumunu ifade eden standartlaştırılmış $X^{2}=1,692$ iyi uyum gösteren değerdedir. $R M R=0,031$ iyi uyum düzeyindedir ve $R M S E A=0,042 ; C F I=0,976 ; T L I=0,966$ iyi uyum aralığındadır. $\mathrm{GFI}=0,961$ ile $\mathrm{NFI}=0,945$ iyi uyum aralığındadır. Bu uyum indeksleri bir bütün olarak değerlendirildiğinde verilerin modele iyi bir şekilde uyduğu gözlenmektedir. 


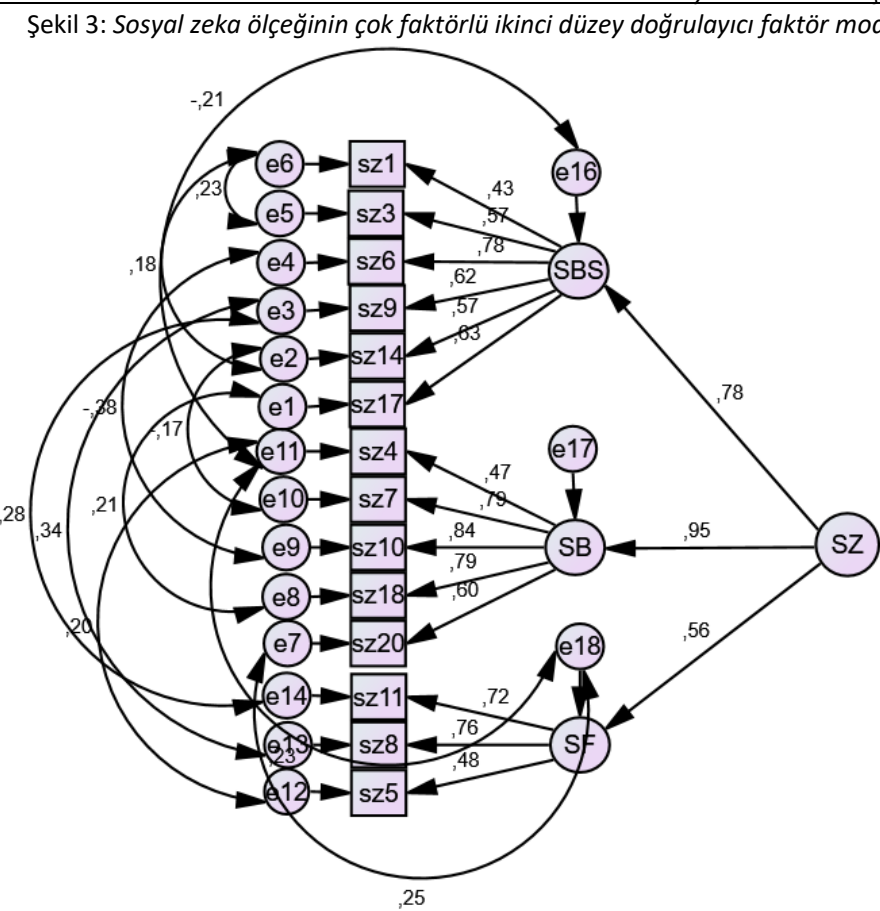

Şekil 4: Örgütsel iletişsim ölçeğinin doğrulayıcı faktör modeli

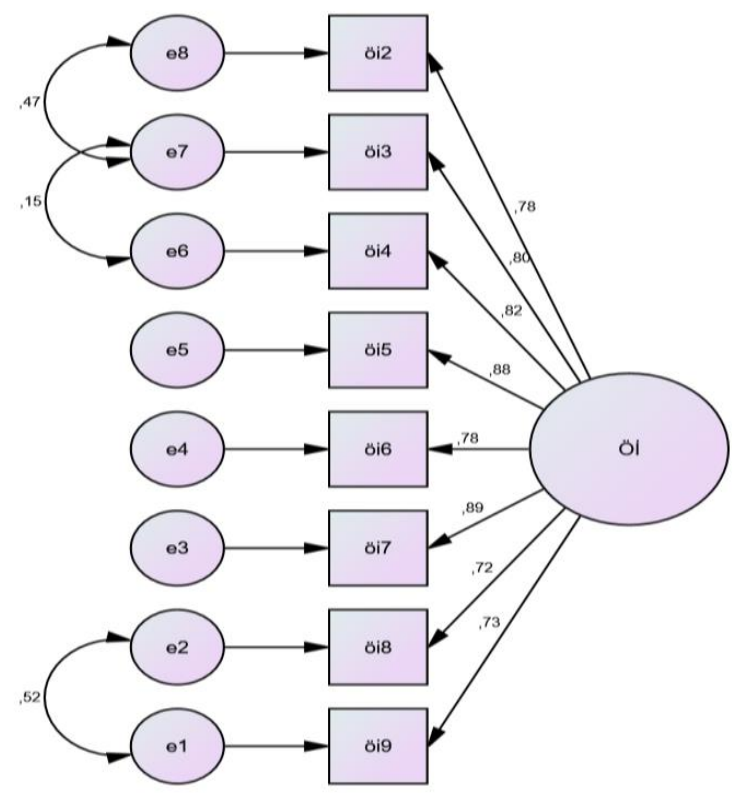

Ölçüm modelinin DFA sonuçları $\chi^{2}(17)=43,818(p \leq 0,05)$ olduğunu göstermektedir. Yukarıda bahsedildiği gibi $X^{2}$ değerinin beklenen anlamlı düzeyindedir. Araştırmada geçerliliği sağlanmış olan örgütsel iletişim ve ifadeleri arasında bir ilişki bulunmaktadır. Tablo $4^{\prime}$ de önerilen uyum indekslerine göre, bir bütün olarak ölçüm modelinin uyumunu ifade eden standartlaştırılmış $X^{2}=2,578$ iyi uyum gösteren değerdedir. $R M R=0,023$ iyi uyum düzeyindedir ve RMSEA=0.064 kabul edilebilir uyum göstermektedir; $\mathrm{CFI}=0,989 ; \mathrm{TLI}=0,982$ iyi uyum aralı̆ındadır. $\mathrm{GFI}=0,970$ ile $\mathrm{NFI}=0,983$ iyi uyum aralı̆ındadır. Bu uyum indeksleri bir bütün olarak değerlendirildiğinde verilerin modele iyi bir şekilde uyduğu gözlenmektedir.

\section{Regresyon Analizine iliş̧kin Bulgular}

Çalışanların sosyal zekalarının örgütsel iletişimlerine etkisini belirlemek amacıyla basit doğrusal regresyon analizi yapılmışır.

\begin{tabular}{|c|c|c|c|c|c|c|}
\hline \multirow{2}{*}{ Bağımlı Değişken } & \multirow{2}{*}{ Bağımsız Değişken } & \multicolumn{2}{|c|}{ Standartlaştırılmamış Katsayılar } & \multirow{2}{*}{$\begin{array}{c}\text { Standartlaştııılmış Katsayılar } \\
\beta\end{array}$} & \multirow{2}{*}{$t$} & \multirow{2}{*}{$p$} \\
\hline & & $B$ & $S E$ & & & \\
\hline \multirow{2}{*}{ Örgütsel İletişim } & (Sabit) & 5,087 & 0,158 & & 32,095 & 0,000 \\
\hline & Sosyal Zeka & $-0,637$ & 0,074 & $-0,402$ & $-8,600$ & 0,000 \\
\hline
\end{tabular}

Düzeltilmiş $R^{2}=0,160, F=73,964, p=0,000, D W=1,628$

Sosyal zeka örgütsel iletişimin \%16'sını açıklamaktadır. Bağımsız değişkenin bağımlı değişken üzerindeki etkisini gösteren model, ANOVA testi sonuçlarına göre anlamlıdır $(p=0,000)$. Yukarıdaki tabloya göre sabit değer ve bağımsız değişkenin katsayısının anlamlı olduğu görülmektedir $(p=0,000 \leq 0,01)$. Modelin $D W$ istatistiği 1,5-2,5 arasında yer aldığı için otokorelasyon olmadığı görünmektedir. Sosyal zeka değişkenine ait regresyon yükü $-0,637$ ve standartlaştııılmış regresyon yükü de $-0,402$ 'dır. Sosyal zeka çalışanlardaki örgütsel iletişimi 0,402 puan düşürmektedir. Sosyal zeka değişkeni örgütsel iletişim değişkenini anlamlı bir şekilde yordamaktadır. 
Tablo 5: Çoklu regresyon analizine ilişkin analiz

\begin{tabular}{|c|c|c|c|c|c|c|c|c|}
\hline \multirow{2}{*}{ Bağımlı Değişken } & \multirow{2}{*}{ Bağımsız Değişken } & \multicolumn{2}{|c|}{$\begin{array}{c}\text { Standartlaştırılmamış } \\
\text { Katsayılar }\end{array}$} & \multirow{2}{*}{$\begin{array}{c}\text { Standartlaştırılmış } \\
\text { Katsayılar }\end{array}$} & \multirow{2}{*}{$t$} & \multirow{2}{*}{$p$} & \multicolumn{2}{|c|}{ Collinearity İstatistiği } \\
\hline & & $B$ & $S E$ & & & & Tolerans & VIF \\
\hline \multirow{4}{*}{ Örgütsel İletişim } & (Sabit) & 5,144 & 0,166 & & 31,013 & 0,000 & & \\
\hline & Sosyal Bilgi Süreci & $-0,374$ & 0,083 & $-0,247$ & $-4,483$ & 0,000 & 0,719 & 1,390 \\
\hline & Sosyal Beceri & $-0,179$ & 0,072 & $-0,150$ & $-2,484$ & 0,013 & 0,602 & 1,660 \\
\hline & Sosyal Farkındalık & $-0,110$ & 0,058 & $-0,103$ & $-1,901$ & 0,058 & 0,739 & 1,352 \\
\hline
\end{tabular}

Düzeltilmiş $R^{2}=0,159, F=25,225, p=0,000, D W=1,629$

Sosyal bilgi süreci, sosyal beceri, sosyal farkındalık değişkenleri birlikte örgütsel iletişim değişkeninin \%15,9'unu açıklamaktadır. Bağımsız değişkenin bağımlı değişken üzerindeki etkisini gösteren model, ANOVA testi sonuçlarına göre anlamlıdır ( $p=0,000 \leq 0,01$ ). Yukarıdaki tabloya göre sabit değer $(p=0,000 \leq 0,01)$ ve bağımsız değişkenlerin (sosyal bilgi süreci $(p=0,000 \leq 0,01)$ ve sosyal beceri $(p=0,013 \leq 0,05))$ katsayılarının anlamlı olduğu görülmektedir. Modelin DW istatistiği 1,5-2,5 arasında yer aldığı için otokorelasyon olmadığı görünmektedir. VIF değeri 10'un altında, tolerans değeri 0,2'nin üstünde olduğu için çoklu doğrusal bağlantı bulunmamaktadır. Sosyal bilgi süreci değişkenine ait regresyon yükü $-0,374$ ve standartlaştırılmış regresyon yükü de $-0,247$; Sosyal beceri değişkenine ait regresyon yükü $-0,179$ ve standartlaştırılmış regresyon yükü -0,150; Sosyal bilgi süreci örgütsel iletişimi $-0,247$ puan, sosyal beceri örgütsel iletişimi $-0,150$ puan düşürmektedir. Sosyal bilgi süreci ve sosyal beceri değişkenleri birlikte örgütsel iletişim değişkenini anlamlı bir şekilde yordamaktadır.

Çoklu doğrusal regresyon modeli: Örgütsel iletişim= 5,144-0,374*Sosyal Bilgi Süreci-0,179*Sosyal Beceri

\section{Bulgulara İlişkin Değerlendirme}

Bu çalışmanın iki ana değişkeni olarak; bireylerle ilişkilerde yetenekli olma ve diğer insanları anlama yeteneği olarak tanımlanan sosyal zeka ve bir örgütün amaç ve hedeflerini gerçekleştirme doğrultusunda bilgi akışını sağlayabilmek adına çalışanların sürekli etkileşim ve işbirliği hâlinde olmaları olarak tanımlanan örgütsel iletişim seçilmiştir. Temellerinde etkileşimin olduğu bu iki değişkenin birbirine olan etkisinin tespit edilmesi amacıyla 385 kişiden oluşan bir örneklem grubuna 8 demografik soru dahilinde 38 ifadenin bulunduğu anket yüz yüze ve çevrimiçi yöntemler ile dağıtılmıştır. Araştırmaya katılanların çoğunluklu tarafları; \%53,8'i kadın, \%36,4'ü 25-32 yaş aralığında, \%55,3'ü bekar, \%55,1'i üniversite mezunu, \%66'sı 4501 TL ve üzeri gelir sahibi, \%91,7'si beyaz yaka, $\% 33,8^{\prime} i$ şuandaki iş yerinde 1 yıldan az süre ile çalışmakta, $\% 45,5^{\prime} i$ ise 9 yıl ve üzeri toplam iş tecrübesine sahip kişilerden oluşmaktadır.

Yapılan fark analizleri doğrultusunda cinsiyet ve medeni duruma ilişkin anlamlı bir farklılık tespit edilememiştir. Yaş, eğitim durumu, gelir düzeyi, görev, şuan ki iş yerindeki tecrübe ve toplam tecrübeye ilişkin yapılan fark analizinde ise anlamlı farklılıklar tespit edilmiştir. Yaşa ilişkin fark analizinde en küçük yaş grubundakilerin diğer gruplara göre örgütsel iletişimlerinin yüksek olduğu tespit edilmiştir ( $p=0,000)$. Kuşaklar açısından değerlendirildiği varsayıldığında Y ve $Z$ kuşağının daha güçlü bir örgütsel iletişimi olduğu söylenebilmektedir. Eğitim düzeyine ilişkin yapılan fark analizinde ise eğitim seviyesi düştükçe artan sosyal zeka $(p=0,006)$, sosyal beceri $(p=0,003)$ ve örgütsel iletişim $(p=0,045)$ bulgular arasında yer almaktadır. Gelir düzeyine ilişkin yapılan fark analizinde ise gelir düzeyi azaldıkça sosyal zeka ( $p=0,000)$, sosyal bilgi süreci $(p=0,000)$, sosyal beceri $(p=0,000)$ ve sosyal farkındalık ( $p=0,000)$ düzeylerinin arttığı, örgütsel iletişim düzeyinin ise gelir düzeyi arttıkça arttığı tespit edilmiştir $(p=0,000)$. Sosyal zeka ve boyutlarının düzeylerinin anlamlı bir farklılık yarattığı diğer bir analiz ise göreve ilişkin fark analizidir; mavi yakanın sosyal zeka ve boyutları düzeylerinin beyaz yakaya göre daha yüksek olduğu tespit edilmiştir ( $p=0,000$ ). Şuan ki iş yerinde tecrübe ve toplam tecrübeye ilişkin yapılan fark analizlerinde ise yıl bazında az tecrübeye sahip çalışanların şuan ki iş yerindeki tecrübeye ilişkin sosyal zeka ( $p=0,030)$, sosyal bilgi süreci $(p=0,018)$ ve örgütsel iletişiminde $(p=0,000)$ diğer gruplara göre daha yüksek olduğu; toplam tecrübeye ilişkin ise örgütsel iletişimlerinin daha yüksek olduğu tespit edilmiştir $(p=0,000)$.

Çalışanların sosyal zekalarının örgütsel iletişimlerine etkisinin araştırıldığı bu çalışmada; sosyal zekanın örgütsel iletişimde pozitif etkisi tespit edilmiştir $\left(R^{2}=0,160\right)$. Bu sonuç doğrultusunda araştırmanın ana hipotezi ve alt hipotezleri olan $\mathrm{H}_{1}, \mathrm{H}_{2}$ ve $\mathrm{H}_{4}$ kısmen kabul edilmektedir. $\mathrm{H}_{3}$ hipotezi ise reddedilmektedir.

\section{Sonuç ve Öneriler}

Örgütlerde bireylerin başarıları birçok faktöre bağlı olarak değişmektedir. Bu faktörlerin en önemlilerinden biri olan sosyal zeka, en basit anlamıyla "anlama yeteneği ve bu yeteneğe bağı ılarak hareket etme" olarak açıklanmaktadır.

Sosyal zekâ, bireyin kendisini ne kadar iyi bir şekilde tanıdığını ve aynı zamanda karşısındaki kişileri, sosyal ortamı da ne kadar iyi bir şekilde anladığını ve sosyal etkileşimini bu şartlar altında kendi istekleri ve çevrenin şartlarına göre mücadele etme yetenekleriyle alakalıdır (Yeh, 2013: 527). Örgüt üyelerini birbirine bağlayan, örgütle çevrenin etkileşimini sağlayan, örgütün oluşmasını ve yaşamasını mümkün kılan ise örgütsel iletişim sürecidir. Ayrı bir kimliği olan örgütün özellikleri iletişimi etkileyebilmektedir. Bu bağlamda sosyal zeka boyutlarından olan sosyal bilgi sürecini yönetebilen, sosyal farkındalık ve sosyal beceri düzeylerini yüksek tutabilen çalışanların sosyal etkileşimleri iyi olacağından mütevelli örgütsel iletişimleri de yüksek olacaktır.

Çalışanların algılanan sosyal zekalarının örgütsel iletişime etkisinin kısmen doğrulandığı bu araştırmanın, literatüre ve sektöre katkı sağlayacağı düşünülmektedir. Bireyler ve işletmeler için önem arz eden bu değişkenler işletme başarısını doğrudan etkilemektedir. Gelecekte üstün rekabet avantajı sağlamak isteyen işletmelerin bu yönde yatırımlar yapması yerinde olacaktır. Çatışmaların yaşanması durumunun muhtemel olduğu işletmelerde, sosyal zekası ve örgütsel iletişimi yüksek düzeydeki bireylerin daha sağlıklı bir iş ortamı yaratması mümkündür. Çatışma yönetiminin etkin olarak işlediği bir ortamda bireylerin problem çözme yetenekleri daha yüksek olacaktır. Bunların neticesinde bireylerin performansları, motivasyonları, iş doyumları, örgütsel bağlılıkları ve örgütsel vatandaşıklarının da artmasının mümkün olduğu söylenebilir. Literatür taramasında detaylı olarak yer verilen araştırmaların bu araştırmanın paralelinde sonuçlar gösterdiğini söylemek mümkündür (Şenkal, 2019; Yıldırım, 2018; Bayram \& Elevli, 2019; Çiftçi, 2019; Aydoğdu, 2016; Yahyazadeh-Jeloudar \& Lotfi-Goodarzi, 2012; Young-Soo, Marcia \& Eun-sil 2019; Hanisha \& Hidayat, 2019).

Araştırmanın belirli sayıda çalışan ile gerçekleştirilmesi kısıtılığını oluşturmaktadır. Gelecekteki araştırmalara yol gösterici olması amacıyla, farklı̈örneklem grupları için çalışma genişletilebilir. Daha yüksek sayıdaki örneklem ile belirli bir sektör bazında araştırma yapılabilir. Ayrıca kamu ve özel sektör olarak karşılaştırmalı değerlendirmeler yapılabileceği de önerilmektedir.

Ayrıca, günümüzde bilgi ve iletişim teknolojilerindeki hızlı değişim ve gelişmelere çalışanların ne derece uyum sağlayabildiği konusunda daha detaylı çalışmalar yapılarak literatüre ve sektöre katkıda bulunulabilir. Araştırmacıların bu çalışmada ele alınan değişkenlere ek olarak 21 . yüzyılın teknolojik gelişmeleri ile birlikte ortaya çıkan yapay zeka ve robotikleşme süreçlerinin çıktıları olan farklı değişkenleri, aracı ve yordayıcı değişkenler olarak katmaları önerilmektedir. İş ve yaşam akışını sadeleştirmek ve kolaylaştırmak adına tüm uygulama ve süreçlerde dijital değişim ve dönüşüme mecbur kalındığı günümüzde, dijitalleşmeye dair değişkenlerin araştırmalara eklenmesinin de önemli ölçüde katkı sağlayacağı düşünülmektedir.

\section{Kaynakça}

Akkaya B. \&Tabak A. (2018). Örgütsel Çeviklik Ölçeğinin Türkçeye uyarlanması: geçerlik ve güvenirlik çalışması. Iş̧ ve insan Dergisi, Cilt:5 Sayı:2, $185-206$.

Anderson, J. C. \& Gerbing, D. W. (1988). Structural equation modeling in practice: a review and recommended two-step approach, Psychological Bulletin, Volume: 103, Number: 3, 411-423.

Arıkan (Sönmezler), E. (2010). Drivers of Brand Extension Success and the Role of Brand Relationship Quality, Boğaziçi University, Unpublished Doctoral Thesis. 
Atak, M. (2005). Örgütlerde resmi olmayan iletişimin yeri ve önemi. Havacılık ve Uzay 74 Teknolojileri Dergisi, Cilt: 2, Sayı: 2, 59-67.

Aydoğdu, T. (2016). Örgütsel iletişim algısının örgütsel vatandaşılı davranışına etkisi: bir araştırma. İnönü Üniversitesi. Sosyal Bilimler Enstitüsü. İşletme Anabilim Dalı. Yönetim ve Organizasyon Bilim Dalı. Yüksek Lisans Tezi.

Bayram A. \& Elevli Ö. (2019). Yaşam doyumunun iş doyumuna etkisinde sosyal zekanın aracı rolü. Bolu Abant İzzet Baysal Üniversitesi Sosyal Bilimler Enstitüsü Dergisi. Cilt:19 Sayı:1. 25-41.

Berk, M. (2016). Sosyal zeka boyutları ile tükenmişlik boyutları arasındaki ilişki: Dumlupınar Üniversitesinde bir uygulama. Dumlupınar Üniversitesi. Sosyal Bilimler Enstitüsü. İşletme Anabilim Dalı. Yüksek Lisans Tezi.

Büyüköztürk, Ş. (2002). Sosyal bilimler veri analizi el kitabı. Ankara: Pegem Akademi Yayınları.

Byrne, B.M. (2001), Structural equation modeling with Amos: basic concepts, applications, and programming. Mahwah, NJ: Lawrence Erlbaum Associates.

Cemaloğlu, N. \& Yıldırım K. (2005). illkokuma yazma öğretimi. Ankara: Nobel Akademi Yayınclık.

Çavuş, M. F., Pekkan, N. Ü. \& Develi, A. (2019). Örgütsel sosyalleşmeye yeni bir öncül: sosyal zeka, Pamukkale Üniversitesi Sosyal Bilimler Enstitüsü Dergisi, Sayı $36,259-272$.

Çelikdemir Zaptçıŏlu, D. \& Paker Tükel, ì. (2019). Örgütsel değişimin gerçekleşmesinde örgütsel iletişimin önemi. İmir iktisat Dergisi, Cilt: 34, Sayı: 3, 431-441

Çiftçi, U.B. (2019). Örgütsel iletişim tarzının örgütsel bağlılık üzerine etkisi: Ostim Organize Sanayi Bölgesi Araştırması. Ufuk Üniversitesi. Sosyal Bilimler Enstitüsü. İşletme Anabilim Dalı. İnsan Kaynakları Bilim Dalı. Yüksek Lisans Tezi.

Çokluk, Ö., Şekercioğlu, G. \& Büyüköztürk, Ş. (2012). Sosyal bilimler için çok değiş̧enli istatistik: Spss ve lisrel uygulamaları. 2. Baskı, Ankara: Pegem Akademi.

Doğan, T., \& Çetin, B. (2009). The validity, reliability and factorial structure of the Turkish version of the Tromso Social Intelligence Scale. Educational Sciences: Theory and Practice, Volume: 9, Number: 2, 709-720.

Dong. Q., Koper R. J. \& Collaço C. M. (2008) Social Intelligence, self-esteem and Intercultural communication sensitivity. Intercultural Communication Studies, XVII:2, 162-172.

Diktaş, G. (2018). Örgütsel sinizm ve sosyal zekânın çalışan performansı ve işten ayrılma niyeti üzerindeki etkisi: Istanbul'daki reklam ajansı çalışanlarına yönelik bir araştırma. Maltepe Üniversitesi. Sosyal Bilimler Enstitüsü. İ̧letme Anabilim Dalı. Yayınlanmamış Yüksek Lisans Tezi.

Durmuş, B., Yurtkoru, E. S. \& Çinko, M. (2018). Sosyal bilimlerde SPSS'le veri analizi, İstanbul: Beta Yayınları.

Güney, S. (2017). Örgütsel davranış, Ankara: Nobel Akademi Yayıncılık.

Gürbüz, S. \& Şahin, F. (2018). Sosyal bilimlerde araştırma yöntemleri felsefe- yöntem- analiz. Ankara: Seçkin Yayıncılık.

Gürgen, H. (1997). Örgütlerde iletişim kalitesi. Der Yayınları, ìstanbul.

Hair, J. F., Black, W. C, Babin, B. J. \& Anderson, R. E. (2010). Multivariate data analysis, 7th Edition, Upper Saddle River, NJ: Prentice Hall.

Hanisha I. \& Hidayat R. (2019). The effect of organizational communication climate on performance of employees in Bright Pln Batam. Advances in Social Science, Education and Humanities Research, Volume: 377, 319-323.

Hatcher, L. (1994). A step-by-step approach to using sas for factor analysis and structural equation modeling, Cary. NC: SAS Institute Inc.

Ho, R. (2014), Handbook of univariate and multivariate data analysis and interpretation with spss, 2nd Edition, Boca Raton: Chapman and Hall CRC Press. Hodges.

Hu, L. T., \& Bentler, P. M. (1999). Cutoff criteria for fit indexes in covariance structure analysis: conventional criteria versus new alternatives, Structural Equation Modeling: a Multidisciplinary Journal, Volume: 6, Number: 1, 1- 55.

Kilıç, S. (2016). Cronbach'ın Alfa güvenirlik katsayısı. Journal of Mood Disorders (JMOOD),6(1), 47-48.

Kılıç, T. \& Saygılı, İ. (2019). Örgütsel Iletişimin Örgütsel Sessizliğe Etkileri: Havacıllık Bakım Merkezlerinde Bir Uygulama. Çukurova Üniversitesi Sosyal Bilimler Enstitüsü Dergisi, 28 (1) , 111-125.

Kihlstrom, J. F., \& Cantor, N. (2000). Social intelligence. In R. J. Sternberg (Ed.), Handbook of intelligence (p. 359-379). Cambridge University Press.

Kline, R. B. (2005). Principles and practice of structural equation modeling, 2 nd Edition, NY: Guilford Publications, Inc.

Kocabaş, F. (2005). Değişime uyum sürecinde iç ve diş örgütsel iletişim çabalarının entegrasyonu gerekliliği. Manas Üniversitesi Sosyal Bilimler Dergisi, Cilt: 7, Sayı: $13,247-252$.

Koçer, C., Yeşil, E. \& Yürüyen, H. (2019). Sanallık algısının, iş yeri yalnızlığı ve örgütsel iletişim üzerindeki etkisi. Uluslararası Turizm, Ekonomi ve Işletme Bilimleri Dergisi, Cilt:2, Sayı:2, $561-577$.

Lacanlale, Erwin P., (2013). Development and Validation of a Social Intelligence Inventory, International Journal of Information and Education Technology, Volume: 3, Number: 2, 263.

Roberts, Karlene H. \& O'Reilly, Charles A. (1974). Measuring organizational communication, Journal of Applied Psychology, Number: 59, Number: 3, 321-326. McGraw-Hill, McShane Steven L. \& Von Glinow Mary Ann (2016). Örgütsel davranış. Ankara: Nobel Akademi Yayıncılık.

Marşap, A. (2017). Çağdaş stratejik yönetişim, Ankara: Nobel Akademi Yayıncılık.

Noar, S. M. (2003). “The role of structural equation modeling in scale development, Structural Equation Modeling, Volume: 10, Number: 4, 622-647.

Özdamar, K. (2002). Paket programlarla istatistiksel veri analizi-1. Eskişehir: Kaan Kitabevi.

Schermelleh-Engel, K., Moosbrugger, H. \& Müller, H. (2003). Evaluating the fit of structural equation models: tests of significance and descriptive goodnessof-fit measures, Methods of Psychological Research Online, Cilt: 8, Sayl: 2, 23-74.

Schumacker, R. E. \& Lomax, R. G. (2004). A beginner's guide to structural equation modeling, 2 nd Edition, New York: Psychology Press.

Silvera, D. H., Martinussen, M. \& Dahl, T. I. (2001). The Tromsù Social Intelligence Scale, a self-report measure of social intelligence. Scandinavian Journal of Psychology, Volume: 42, 313-319.

Şenkal, F. (2019). Çalışanların sosyal zeka seviyelerinin çatışma yönetimi tarzlarına etkisi. Dokuz Eylül Üniversitesi. Sosyal Bilimler Enstitüsü. İşletme Anabilim Dalı. Yüksek Lisans Tezi.

Şeşen, H. \& Meydan, C. (2011). Yapısal eşitlik modellemesi amos uygulamaları, Ankara: Detay Yayıncılık.

Şimşek, Ö. F. (2007), Yapısal eşitlik modellemesine giriş, Ankara: Ekinoks Yayınları.

Tabachnick, B. G. \& Fidel, L. S. (2001). Using multivariate statistics, 4th Edition, MA: Allyn \& Bacon, Inc.Boston.

Tdk. İletişim tanımı. Erişim tarihi: 24.05.2020, https://sozluk.gov.tr/

Tekin E. (2019). Sosyal zekânın akademik performans üzerindeki etkisinde kültürel zekânın düzenleyici rolü. Uluslararası Ekonomi ve Yenilik Dergisi, Cilt: 5, Sayı: 2, 115-135.

Thorndike, E. L. (1920). Intelligence and its uses. Harper's magazine, 140, 227- 235.

Topses, G. (2009), Gelişim ve öğrenme psikolojisi, Ankara: Nobel Akademi Yayıncıllı.

Tutar, H. (2003). Örgütsel iletişim, Ankara: Seçkin Yayıncılık.

Usluel, Y.K., Demir, Ö. \& Çınar, M. (2014). Sosyal ağların kullanım amaçları ölçeği, Eğitim Teknolojileri Araştırma Dergisi, Cilt: 5, Sayı: 2, 35-53.

Yahyazadeh- Jeloudar S. \& Lotfi-Goodarzi F. (2012). The relationship Between Socian İntelligence and Job Satisfaction Among MA and BA Teachers. International Journal of Educational Sciences. Volume: 4, Number: 3, 209-213.

Yeh, Z. T. (2013). Role of theory of mind and executive function in explaining social intelligence: A structural equation modeling approach, Aging \& Mental Health, Volume: 17, Number: 5, 527-534.

Yıldırım Z. (2018). Sosyal zekanın problem çözme becerisine etkisi: Ankara ilinde görev yapan siyasetçiler üzerinde bir uygulama. Çankaya Üniversitesi. Sosyal Bilimler Enstitüsü. İ̧̧letme Anabilim Dalı. Yüksek Lisans Tezi.

Yılmaz, P. (2019). Ögrretmen algılarına göre okul müdürlerinin dönüşümcü liderlik davranışları ile örgütsel iletişim arasındaki ilişkinin incelenmesi. İstanbul Sabahattin Zaim Üniversitesi. Sosyal Bilimler Enstitüsü. Eğitim Bilimleri Anabilim Dalı. Eğitim Yönetimi ve Denetimi Bilim Dalı. Yüksek Lisans Tezi. 
irge, N. T., Özkan, A., Kaynak, Ö.M.

Sakarya Üniversitesi İşletme Enstitüsü Dergisi,(2020): 113-121

Young-Soo L., Marcia L. \& Eun-Sil C. (2019). The effects of job satisfaction on organizational commitment in Korea dental hygienist: organizational communication mediation model. Indian Journal of Public Health Research \& Development, Volume: 10, Number: 6, 751-757. 